\title{
DIMENSI KARAKTERISTIK LAPORAN KEUANGAN PEMERINTAH
}

\section{DIMENSIONS OF GOVERNMENT FINANCIAL REPORT CHARACTERISTICS}

\author{
Anwar $^{1)}$, Asbi Amin'2)* \\ Prodi Akuntansi, STIEM Bongaya Makassar \\ anwar@stiem-bongaya.ac.id ${ }^{l)}$ asbi.amin@stiem-bongaya.ac.id ${ }^{2)}$
}

\begin{abstract}
This research to prove the commitment of the leadership, the capacity of the financial apparatus, the implementation of the Regional Financial Accounting Standards, and the internal control function have an influence on the characteristics of government financial reports. This research is a quantitative study using primary data. The population in this study were senior auditors of the South Sulawesi Representative Audit Board using a purposive sampling technique so that the sample was sixty-eight auditors. The data were collected by using a questionnaire method. The analytical method used in testing the hypothesis is multiple linear regression analysis. The results of the study prove that the commitment of the leadership, the capacity of the financial apparatus, the application of the Regional Financial Accounting Standards, and the internal control function significantly influence the characteristics of government financial reports.
\end{abstract}

Keywords: leadership commitment, the capacity of financial Apparatur, the implementation of government accounting standards, internal control, the quality of local government financial statements

\begin{abstract}
ABSTRAK
Penelitian ini bermaksud untuk membuktikan komitmen pimpinan, kapasitas Aparatur keuangan, implementasi Standar Akuntansi Keuangan Daerah dan fungsi internal control memiliki pengaruh terhadap karakteristik laporan keuangan pemerintah. Penelitian ini adalah penelitian kuantitatif dengan menggunakan data primer. Populasi dalam penelitian ini adalah auditor senior Badan Pemeriksa Keuangan Perwakilan Sulawesi Selatan dengan menggunakan teknik purposive sampling sehingga sampel berjumlah enam puluh delapan auditor. Pengumpulan data dilakukan dengan metode kuesioner. Metode analisis yang digunakan dalam menguji hipotesis adalah analisis regresi linear berganda. Hasil penelitian membuktikan bahwa komitmen pimpinan, kapasitas Aparatur keuangan, penerapan Standar Akuntansi Keuangan Daerah dan fungsi internal control signifikan memengaruhi karakteristik laporan keuangan pemerintah.
\end{abstract}

Kata kunci: Komitmen pimpinan, kapasitas Aparatur keuangan, implementasi Standar Akuntansi Keuangan Daerah, Fungsi internal control, karakteristik laporan keuangan pemerintah.

*Corresponding author

Email: asbi.amin@stiem-bongaya.ac.id

DOI: https://doi.org/10.33369/j.akuntansi.10.3.223-230

\section{PENDAHULUAN}

Berhasil atau tidaknya pengelolaan keuangan pemerintah dan kinerjanya saati ini sudah dapat diketahui melalui media digital yakni website (internet) resmi pemerintah masing-masing daerah/kabupaten. Laporan keuangan daerah yang komprehensif sebagai instrument yang menjembatani akuntabilitas publik (Superdi, 2017). Syarat wajib bagi laporan keuangan pemerintah adalah memiliki karakteristik laporan keuangan berupa relevan, andal, dapat dipercaya, dapat dibandingkan dan dapat dipahami. (Peraturan Pemerintah No.71 tahun 2010). 
Wujud dari Laporan Keuangan Pemerintah Daerah (LKPD) terlihat dalam Ikhtisar Hasil Pemeriksaan Semester (IHPS) yang dikeluarkan oleh Badan Pemeriksa Keuangan (BPK) pada gambar berikut :

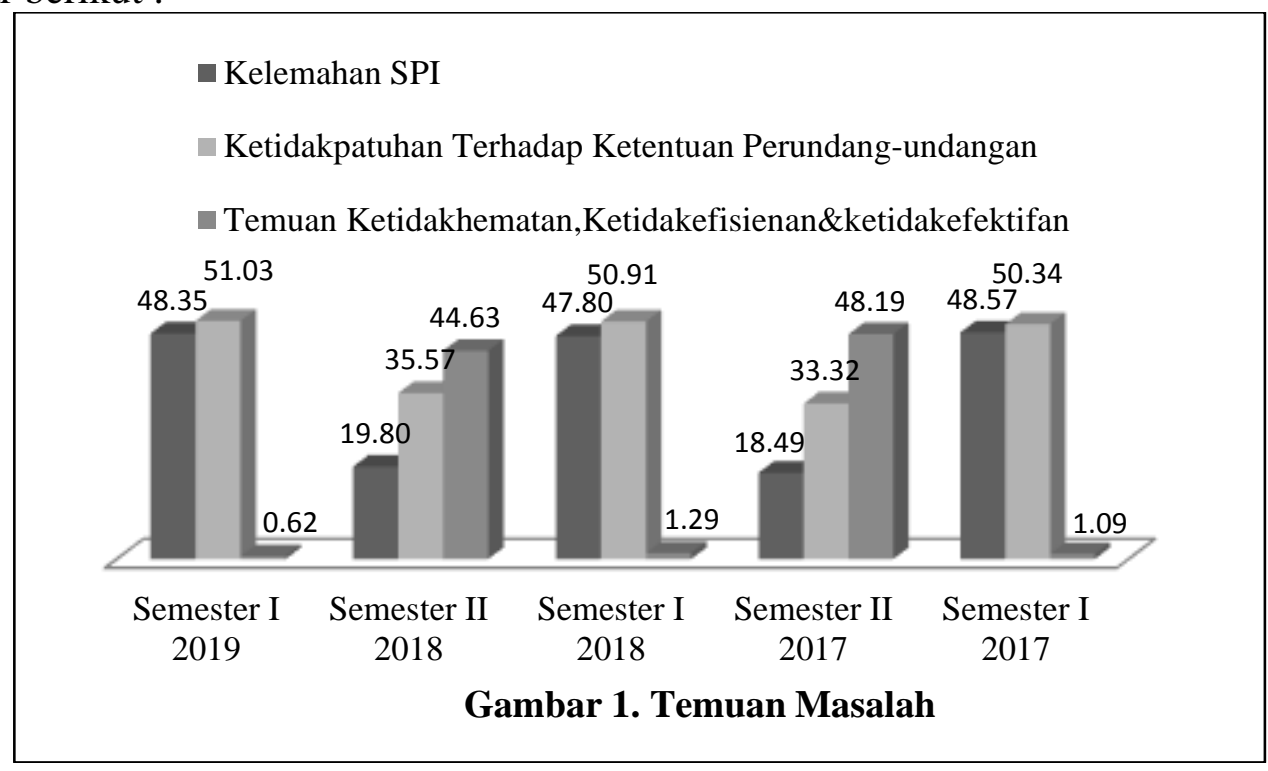

Sumber : www.bpk.go.id (IHPS, diolah)

Rekapituasi IHPS BPK atas LKPD dari semester I tahun anggaran 2017 sampai semester I tahun anggaran 2019, memperlihatkan temuan atas masalah lemahnya Sistem Pengendalian Intern (SPI) mengalami peningkatan sebesar $28,55 \%$ terlihat pada gambar dimana semester II Tahun 2018 kelemahan SPI sebesar 19,80\% meningkat di semester I tahun 2019 sebesar $48,35 \%$. Sementara itu, masalah ketidakpatuhan pada peraturan perundang-undangan juga mengalami peningkatan sebesar 15,46\% dari semester II tahun 2018 sebesar 35,57 meningkat di semester I tahun 2019 sebesar 51,03\%. Disisi lain, temuan ketidakhematan, ketidakefisienan dan ketidakefektifan memperlihatkan penurunan signifikan sebesar 44,01\%. Penurunan ini terlihat dari semester II tahun anggaran 2018 sebesar 44,63\% turun disemester I 2019 sebesar $0,62 \%$. Persentase ketidakpatuhan pada peraturan perundang-undangan yang setiap tahun masih diatas $50 \%$ berpotensi menyebabkan kerugian pada kas Negara dan berkaitan dengan pelaksanaan akuntansi yang menggambarkan kualitas dari laporan keuangan pemerintah. Oleh karena itu, pemerintah wajib memperhatikan karakteristik laporan keuangannya agar meminimalisasi temuan dari BPK (Sumber : www.bpk.go.id, 2020).

Salah satu dimensi yang berperan penting dalam memengaruhi karakteristik laporan keuangan yaitu komitmen pimpinan atau kepala daerah. Kepala daerah sebagai penyelenggara pengelolaan keuangan daerah yang mempunyai otoritas tertinggi dan kunci atas suksesnya pengelolaan keuangan daerah yang dipimpinnya. Karaktersitik laporan keuangan tanpa didukung oleh aparatur keuangan yang memahami bidang Akuntansi Pemerintahan tidak akan bisa mengelola keuangannya dengan baik. Kapasitas aparatur keuangan adalah keadaan dimana aparatur keuangan dapat menyelesaikan tugas dan tanggung jawab dalam pengelolaan keuangan daerah dengan modal pendidikan, pelatihan dan pengalaman.

Dimensi yang juga tidak kalah pentingnya dalam membantu menghasilkan karakteristik laporan keuangan pemerintah daerah yaitu implementasi Sistem Akuntansi Pemerintah Daerah (SAKD). SAKD adalah tahap akuntansi mulai dari data yang dikumpulkan, tahap pencatatan, tahap pengikhtisaran, sampai tahap penyusunan laporan keuangan guna mempertangungjawaban pelaksanaan Anggaran Pendapatan dan Belanja Daerah (APBD). (Permendagri No. 59 Tahun 2007). 
Fungsi internal control juga sebagai dimensi yang dapat memengaruhi karakteristik laporan keuangan mengingat jika fungsi internal control efektif maka tujuan organisasi yakni kegiatan dapat berjalan efektif dan efisien. Peran Internal control juga dapat mengamankan asset Negara, dapat mengontrol, ketaatan terhadap peraturan perundang-undangan dan dapat menghasilkan transaksi yang akuntabel pada tiap kegiatan.

Hasil penelitian terkait dengan kualitas laporan keuangan dilakukan oleh peneliti terdahulu diantaranya (Tampubolon \& Hasibuan, 2019) menemukan bahwa komitmen organisasi dan kompetensi sumber daya manusia signifikan memengaruhi kualitas laporan keuangan. (Sari \& Fadli, 2017) menemukan bahwa kualitas laporan keuangan dipengaruhi oleh penerapan sistem akuntansi pemerintah. Sementara (Andriani, Suarsa, \& Yuniati, 2019) membuktikan bahwa kualitas laporan keuangan dipenaruhi oleh sistem pengendalian internal.

Peneliti termotivasi untuk mengembangkan penelitian ini karena adanya fenomena yang diuraikan di atas dan hasil-hasil penelitian terdahulu. Penelitian ini juga mengembangkan hasil penelitian terdahulu (Andini \& Yusrawati, 2015) yang telah meneliti tentang Kualitas Laporan Keuangan Daerah dipengaruhi oleh Kompetensi Sumber Daya Manusia dan Sistem Akuntansi Keuangan Daerah dan hasil penelitiannya dapat membuktikan hipotesis. Variabel yang peneliti kembangkan yaitu komitmen pimpinan dan fungsi internal control. Disisi lain, tempat penelitian ini juga berbeda dengan penelitian yang telah dilakukan oleh (Andini \& Yusrawati, 2015).

\section{KERANGKA TEORITIS DAN HIPOTESIS}

\section{Agency Theory}

Teori keagenan (agency theory) terkait aksi pemerintah daerah dalam memberikan informasi bagaimana keuangannya dikelola sesuai target yang telah direncanakan sebagai wujud akutabilitas. Pemerintah sebagai agen dan rakyat sebagai prinsipal. (Falistina, 2011). Teori keagenan dalam penelitian ini juga menjelaskan kepercayaan publik akan kemampuan pemerintah daerah menyelesaikan kewajibannya membuat pertanggungjawaban keuangan dengan tepat sesuai dengan kebutuhan rakyatnya. Untuk melaksanakan tanggung jawab tersebut dibutuhkan komitmen pimpinan, kapasitas SDM, implementasi SAKD dan fungsi internal control yang berjalan maksimal guna menghasilkan karakteristik laporan keuangan sesuai standar.

\section{Pengaruh Komitmen Pimpinan Terhadap Karakteristik Laporan Keuangan}

Komitmen organisasi merupakan sikap aparatur pemerintah yang memengaruhi keputusannya untuk tetap berkerja dengan loyalitas tinggi untuk mencapai tujuan organisasi. Kepala daerah yang memiliki komitmen akan menimbulkan rasa ikut memiliki daerahnya, sehingga termotivasi melaksanakan semua kegiatan yang berpihak pada kebutuhan rakyatnya dan melaporkan semua aktivitas tersebut melalui laporan keuangan yang mempunyai karakteristik. Komitmen organsisasi ditemukan berpengaruh terhadap kualitas laporan keuangan oleh (Manimpurung, Kalangi, \& Gerungai, 2018) dan (Nugroho \& Setyowati, 2019). Namun, hasil yang berbeda ditemukan oleh (Tampubolon \& Hasibuan, 2019) menunjukkan bahwa komitmen organisasi positif tidak signifikan terhadap kualitas laporan keuangan. Maka, hipotesis penelitian ini :

$\mathrm{H}_{1}$ : Komitmen pimpinan berpengaruh positif dan signfikan terhadap karakteristik laporan keuangan pemerintah.

\section{Pengaruh Kapasitas Aparatur Keuangan berpengaruh terhadap Karakteristik Laporan Keuangan Pemerintah.}


Kapasitas aparatur keuangan yang belatar belakang pendidikan akuntansi atau yang telah mengikuti pelatihan cara mengelola keuangan pemerintah dan terus belajar menambah keahlian dibidang akuntansi. Apabila aparatur keuangan memiliki Ilmu akuntansi dan mengetahui aturan-perundang-undangan yang digunakan untuk mengolah keuangan pemerintah maka akan mampu menyusun laporan keuangan yang mempunyai karaktersitik sesuai standar pemerintah. Hasil penelitian (Martini, 2018), (Andrianto \& Rahmawati, 2018) dan (Yaqin \& Jatmiko, 2018)menyatakan bahwa kapasitas sumber daya manusia berpengaruh terhadap kualitas laporan keuangan. Namun, berbeda dengan hasil penelitian (Manimpurung, Kalangi, \& Gerungai, 2018) membuktikan bahwa kapasitas sumber daya manusia tidak signifikan berpengaruh terhadap kualitas laporan keuangan. Maka hipotesis :

$\mathrm{H}_{2}$ : Kapasitas aparatur keuangan berpengaruh positif dan signikan terhadap Karakteristik Laporan Keuangan Pemerintah.

\section{Pengaruh Implementasi Sistem Akuntansi Keuangan Daerah berpengaruh terhadap Karakteristik Laporan Keuangan Pemerintah.}

Implementasi Sistem Akuntansi Keuangan Daerah (SAKD) dianggap dapat menggambarkan catatan dan laporan atas transaksi keuangan yang akuntabel yang terjadi di satuan kerja pemerintah agar dapat mempermudah pengambilan keputusan ekonomi yang berpihak pada kepentingan masyarakat. Hasil penelitian (Lisda, Nurwulan, \& Alifa, 2018) dan (Wulandari, 2018) menunjukkan bahwa SAKD berpengaruh signifikan terhadap kualitas laporan keuangan. Maka, hipotesis :

$\mathrm{H}_{3}$ : Implementasi Sistem Akuntansi Keuangan Daerah berpengaruh positif dan signifikan terhadap Karakteristik Laporan Keuangan Pemerintah.

\section{Pengaruh Fungsi Internal Control berpengaruh terhadap Karakteristik Laporan Keuangan Pemerintah.}

Internal control yang baik berfungsi mengurangi resiko kesalahan dan melindungi organisasi dari tindakan kecurangan Internal control pada laporan keuangan dibuat agar para pelaku akuntansi menaati acuan dan aturan yang telah ditetapkan dan berlaku saat periode pengelolaan keuangan. Hasil penelitian (Martini, 2018), (Agung, 2018) dan (Ramadhani \& Soerono, 2019) menemukan bahwa sistem pengendalian intern berpengaruh terhadap kualitas laporan keuangan pemerintah. Maka hipotesis :

$\mathrm{H}_{4}$ : Fungsi internal control berpengaruh positif dan signfikan terhadap Karakteristik Laporan Keuangan Pemerintah.

Penjelasan di atas dapat digambarkan dalam kerangka pemikiran berikut :

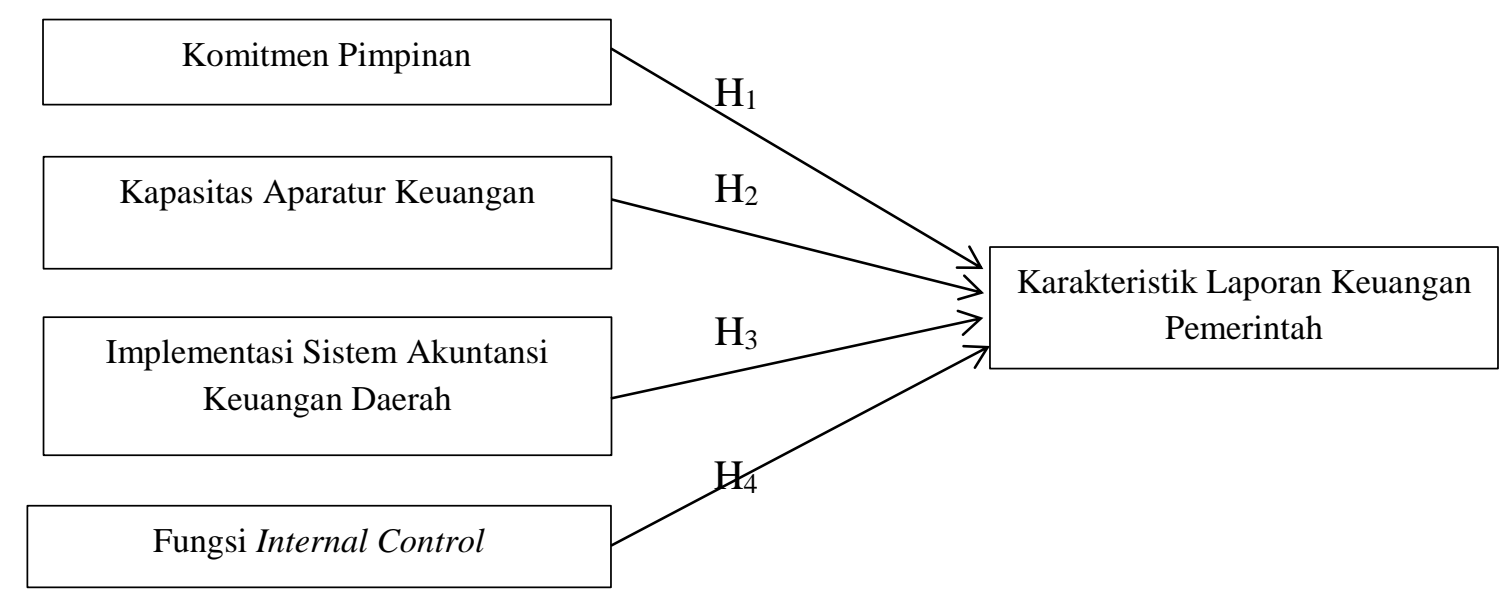




\section{Gambar 1. Kerangka Pemikiran}

\section{METODE PENELITIAN}

Penelitian ini bersifat kuantitatif untuk menguji keandalan suatu teori sehingga mendapatkan kesimpulan. (Sugiyono, 2015). Data penelitian ini dikumpulkan melalui kuesioner yang diberikan kepada auditor senior BPK Perwakilan Sulawesi Selatan yang mengaudit 25 pemerintah daerah di Sulawesi Selatan. Teknik purposive sampling dipakai dengan alasan responden melakukan pemeriksaan atas LKPD sehingga mengetahui faktor yang paling berpengaruh terhadap karakteristik laporan keuangan pemerintah daerah sebanyak 68 auditor. Data penelitian diolah dengan metode regresi linier berganda.

\section{HASIL DAN PEMBAHASAN}

Setelah melakukan penyebaran kuesioner, statistik deskriptif yang dihasilkan adalah sebagai berikut :

Tabel 1. Statistik Deskriptif

\begin{tabular}{l|c|c|c|c|c}
\hline Keterangan & $\mathrm{N}$ & Minimum & Maksimum & Mean & Standar Deviasi \\
\hline Komitmen pimpinan & 68 & 2,91 & 5,00 & 4,12 & 0,475 \\
\hline Kapasitas Aparatur keuangan & 68 & 3,09 & 4,64 & 3,86 & 0,335 \\
\hline Implementasi SAKD & 68 & 2,70 & 4,90 & 4,24 & 0,427 \\
\hline Fungsi Internal Control & 68 & 2,78 & 5,00 & 4,04 & 0,465 \\
\hline Karakteristik Laporan keuangan & 68 & 2,90 & 5,00 & 4,19 & 0,394 \\
\hline
\end{tabular}

Sumber : Data diolah, SPSS V.23 (2019)

Output tabel memperlihatkan jawaban responden terhadap variabel komitmen pimpinan bernilai minimum 2,91 , nilai maksimum 5 , nilai mean 4,12 dan standar deviasi 0,475 . Untuk variabel kapasitas aparatur keuangan bernilai minimum 3,09, nilai maksimum 4,64, nilai mean 3,86 dan standar deviasi 0,335. Nilai minimum variabel implementasi SAKD sebesar 2,70 nilai maksimum 4,90, nilai mean 4,24 dan standar deviasi 0,427. Variabel fungsi internal control bernilai minimum 2,78, nilai maksimum 5, nilai mean 4,04 dan standar deviasi 0,465. Sementara karakteristik laporan keuangan bernilai minimum 2,90, nilai maksimum 5, nilai mean 4,19 dan standar deviasi 0,394 yang berarti respon dari responden atas pertanyaan disetiap variabel bervariasi. Hasil uji multikolinearitas disajikan pada tabel uji multikolinearitas sebagai berikut :

Tabel 2. Uji Multikolinearitas

\begin{tabular}{l|c|c|c}
\hline \multirow{2}{*}{ Model } & \multicolumn{2}{|c|}{ Collinearity Statistic } & \multirow{2}{*}{ Keputusan } \\
\cline { 2 - 3 } & Tolerance & VIF & \multirow{2}{*}{ Tidak terjadi Multikolinearitas } \\
\hline Komitmen pimpinan & .809 & 1.236 & Tidak terjadi Multikolinearitas \\
\hline Kapasitas Aparatur keuangan & .177 & 5.657 & Tidan \\
\hline Implementasi SAKD & .218 & 4.596 & Tidak terjadi Multikolinearitas \\
\hline Fungsi Internal Control & .228 & 4.388 & Tidak terjadi Multikolinearitas \\
\hline
\end{tabular}

Sumber : Data Diolah SPSS V. 23.00 (2019)

Output tabel di atas menunjukkan bahwa masing-masing variabel bebas bernilai toleransi $>0,1$ dan VIF $<10$ dan sehingga tidak terjadi multikolinearitas yang mengganggu model. Hasil Uji koefisien determinasi adalah sebagai berikut :

Tabel 3. Koefisien Determinasi

\begin{tabular}{l|l} 
Keterangan & Hasil \\
\hline
\end{tabular}




\begin{tabular}{l|l}
\hline $\mathrm{R}$ & .897 \\
\hline R Square & .805 \\
\hline Adjusted R & .792 \\
\hline Sumber : Data Diolah SPSS V. & $23.00(2019)$
\end{tabular}

Sumber : Data Diolah SPSS V. 23.00 (2019)

Output koefisien determinasi menjelaskan bahwa Adjusted R square sebesar 79,2\% yang berarti bahwa komitmen pimpinan, kapasitas aparatur keuangan, penerapan SAKD dan fungsi internal control memberikan kontribusi pada karakteristik laporan keuangan pemerintah. Hasil uji hipotesis disajikan pada tabel berikut ini :

Tabel 4. Uji Hipotesis

\begin{tabular}{lcccc}
\hline \multicolumn{1}{c}{ Variabel } & $\mathrm{B}$ & $\mathrm{t}$ & Sig. & Keterangan \\
\hline Komitmen pimpinan & .223 & 2.543 & .013 & Hipotesis Diterima \\
Kapasitas Aparatur keuangan & .316 & 2.148 & .036 & Hipotesis Diterima \\
Implementasi SAKD & .295 & 2.418 & .019 & Hipotesis Diterima \\
Fungsi Internal Control & .359 & 2.550 & .013 & Hipotesis Diterima \\
\hline Sur
\end{tabular}

Sumber : Data Diolah, (2019)

Ouput tabel menunjukkan persamaan model sebagai berikut :

Karakteristik Laporan Keuangan Pemerintah $=-0,777+0,223 \mathrm{X} 1+0,316 \mathrm{X} 2+0,295 \mathrm{X} 3+0,359 \mathrm{X} 4+\mathrm{e}$ Keterangan :

$\mathrm{Y}=$ Karakteristik Laporan Keuangan Pemerintah

$\mathrm{X} 1 \quad=$ Komitmen pimpinan

$\mathrm{X} 2=$ Kapasitas aparatur keuangan

$\mathrm{X} 3 \quad=$ Implementasi SAKD

$\mathrm{X} 4 \quad=$ Fungsi Internal cotrol

\section{Pembahasan}

\section{Pengaruh Komitmen Pimpinan Terhadap Karakteristik Laporan Keuangan}

Hasil penelitian ini yang membuktikan bahwa komitmen pimpinan signifikan memengaruhi karakteristik laporan keuangan. Pimpinan daerah yang memiliki komitmen yang tinggi akan berupaya bekerja maksimal dan menghasilkan karakteristik laporan keuangan yang berpihak pada kepentingan rakyatnya dan meningkatkan kinerja para aparaturnya dengan memotivasi agar mendapat opini BPK yang sesuai dengan target kerja organisasi. Komitmen pimpinan adalah variabel yang paling dominan memengaruhi karakteristik laporan keuangan karena kepala daerah yang mempunyai komitmen pimpinan yang tinggi cenderung bekerja untuk kepentingan masyarakat sehingga akan karakteristik laporan keuangan yang dihasilkan akan memuaskan. Hasil penelitian mendukung penelitian yang dilakukan oleh (Manimpurung, Kalangi, \& Gerungai, 2018) dan (Nugroho \& Setyowati, 2019) yang menemukan bahwa komitmen organsisasi berpengaruh terhadap kualitas laporan keuangan. Namun, hasil penelitian ini berbeda dengan hasil penelitian yang telah ditemukan oleh (Tampubolon \& Hasibuan, 2019) menunjukkan bahwa komitmen organsasi positif tidak signifikan terhadap kualitas laporan keuangan.

\section{Pengaruh Kapasitas Aparatur Keuangan Terhadap Karakteristik Laporan Keuangan.}

Hasil penelitian ini yang membuktikan bahwa kapasitas aparatur keuangan memengaruhi karakteristik laporan keuangan. Kapasitas aparatur keuangan menggambarkan hasil kerja aparatur dalam mengelola laporan keuangan dengan ilmu, keahlian dan lama kerjanya menentukan keberhasilan karakteristik laporan keuangan yang dihasilkannya. Hasil penelitian ini terdukung oleh hasil penelitian (Martini, 2018), (Andrianto \& Rahmawati, 2018) dan (Yaqin \& Jatmiko, 2018) yang semuanya menemukan bahwa kapasitas sumber daya manusia berpengaruh terhadap kualitas laporan keuangan. Namun, hasil penelitian ini tidak sama dengan hasil penelitian (Manimpurung, Kalangi, \& Gerungai, 2018) yang menemukan 
bahwa kapasitas sumber daya manusia tidak signifikan berpengaruh terhadap kualitas laporan keuangan.

\section{Pengaruh Implementasi Sistem Akuntansi Keuangan Daerah berpengaruh terhadap Karakteristik Laporan Keuangan Pemerintah.}

Hasil penelitian ini membuktikan bahwa Implementasi Sistem Akuntansi Keuangan Daerah (SAKD) memengaruhi karakteristik laporan keuangan. Implementasi Sistem Akuntansi Keuangan Daerah (SAKD) di satuan kerja dianggap dapat menggambarkan catatan dan laporan atas transaksi keuangan yang akuntabel yang terjadi di satuan kerja pemerintah agar dapat mempermudah pengambilan keputusan ekonomi yang berpihak pada kepentingan masyarakat. Hasil penelitian ini mendukung hasil penelitian (Lisda, Nurwulan, \& Alifa, 2018) dan (Wulandari, 2018) menunjukkan bahwa signifikansi pengaruh sistem akuntansi keuangan daerah pada kualitas laporan keuangan.

\section{Pengaruh Fungsi Internal Control berpengaruh terhadap Karakteristik Laporan Keuangan Pemerintah.}

Hasil penelitian ini membuktikan bahwa Internal control memengaruhi karaktersitik laporan keuangan. Internal control sebagai sistem yang diterapkan berperan mengurangi resiko kesalahan dan melindungi organisasi dari tindakan kecurangan Internal control pada laporan keuangan dibuat agar para pelaku akuntansi menaati acuan dan aturan yang telah ditetapkan dan berlaku saat periode pengelolaan keuangan. Hasil penelitian ini mendukung hasil penelitian (Martini, 2018), (Agung, 2018) dan (Ramadhani \& Soerono, 2019) yang menemukan bahwa sistem pengendalian intern berpengaruh terhadap kualitas laporan keuangan pemerintah.

\section{SIMPULAN DAN SARAN}

Hasil penelitian ini menemukan bahwa komitmen pimpinan, kapasitas aparatur keuangan, implementasi sistem akuntansi keuangan daerah dan fungsi internal control signifikan karakteristik laporan keuangan pemerintah. Komitmen pimpinan adalah variabel yang paling dominan memengaruhi karakteristik laporan keuangan karena kepala daerah yang mempunyai komitmen pimpinan yang tinggi cenderung bekerja untuk kepentingan masyarakat sehingga karakteristik laporan keuangan yang dihasilkan akan memuaskan. Selain itu, penelitian ini menyarankan agar kapasitas aparatur keuangan lebih ditingkatkan dengan banyak diikutkan pelatihan ataupun diklat yang terkait dengan pengelolaan keuangan.

\section{Ucapan Terima Kasih}

Peneliti mengucapkan terima kasih kepada Direktorat Pengelolaan Kekayaan Intelektual, Direktorat Jenderal Penguatan Riset Pengembangan Kementrain Riset, Teknologi dan Pendidikan Tinggi yang telah memberi kesempatan mengikuti Klinik Penulisan Artikel Ilmiah Nasional dan artikel ini sebagai ouput dari kegiatan tersebut.

\section{REFERENCES}

Agung, T. M. (2018, Mei). Analisis Faktor-faktor Yang Mempengaruhi Kualitas Laporan Keuangan Pemerintah Daerah Kabupaten Kerangasem. e-Jurnal Akuntansi Udayana, 23(2).

Andini, D., \& Yusrawati. (2015, Juni). . Pengaruh Kompetensi Sumber Daya Manusia dan Penerapan Sistem Akuntansi Keuangan Daerah Terhadap Kualitas Laporan Keuangan Daerah. Jurnal Ekonomi, manajemen, Akuntansi I, 24(1). 
Andriani, P., Suarsa, A., \& Yuniati, Y. (2019). Pengaruh Pengendalian Internal Terhadap Kualitas Laporan keuangan Pada PDAM Tirtawening Kota Bandung. SEMAR Sain Ekonomi Manajemen\&Akuntansi, 1(3).

Andrianto, E., \& Rahmawati, D. (2018). Pengaruh Kapsitas Sumber Daya Manusia, Pemanfaatan Teknologi Informasi dan Sistem Pengendalian Intern Pemerintah Terhadap Kualitas Laporan Keuangan Pemerintah Daerah Dengan Komitmen Organisasi Sebagai Variabel Moderasi. Profita : Kajian Ilmu Akuntansi, 6(2).

Falistina, R. (2011). Faktor-faktor yang Mempengaruhi Keandalan dan Timeliness Pelaporan Keuangan Badan Layanan Umum, Studi pada BLU di Kota Semarang. Jurnal Fakultas Ekonomi,. Jurnal Ekonomi Universitas Diponegoro, 1(1).

Lisda, R., Nurwulan, L. L., \& Alifa, R. A. (2018). Pengaruh Penerapan SAKD, Kapasitas SDM dan Pemanfaatan Teknologi Informasi Terhadap Kualitas LKPD. Konferensi Nasional Sistem Informasi. Pangkalpinang.

Manimpurung, R., Kalangi, L., \& Gerungai, N. (2018). Pengaruh Kapasitas Sumber Daya Manusia dan Komitmen Organisasi Terhadap Kualitas Laporan Keuangan Pemerintah Daerah Pada badan Pengelola Keuangan dan Aset Daerah (BPKAD) Kota Manado. Jurnal Riset Akuntansi Going Concern, 13(2), 241-250.

Martini, N. R. (2018, Januari). Pengaruh Kapasitas Sumber Daya Manusia dan Pengendalan Intern Akuntansi Pada Pelaporan Keuangan Satuan Kerja Perangkat Daerah (SKPD) Kabupaten Gianyar. Jurnal Krisna : Kumpulan Riset Akutansi, 9(2).

Nugroho, F. A., \& Setyowati, W. (2019, Oktober). Pengaruh Komitmen Organsasional, Sistem Informasi Akuntansi, dan Peran Audit Internal Terhadap Kualias Laporan Keuangan. ECONBAN, 1(2).

Peraturan Pemerintah No. 71 Tahun 2010 Tentang Standar Akuntansi Pemerintahan. 2010. Jakarta. Kementrian Keuangan Republik Indonesia.

Permendagri No. 59 Tahun 2007 tentang Pedoman Pengelolaan Keuangan Daerah. Jakarta.

Ramadhani, M., \& Soerono, A. N. (2019). Pengaruh Sumber Daya Manusia, Sistem pengendalian Intern, Teknologi Informasi dan Pemahaman Basis Akrual Terhadap Kualitas Laporan Keuangan Pemerintah Daerah. Jurnal Riset Akuntansi Terpadu, 12(1).

Sari, G. I., \& Fadli, F. (2017). Analisis Faktor-faktor Yang Mempengaruhi Kualitas Laporan Keuangan Daerah. Jurnal Akuntansi Universitas Bengkulu, 7(3).

Sugiyono. (2015). Metode Penelitian (Metode Kuantitatif, Kualitatif, $R \& D$ ). . Bandung: Alfabeta.

Superdi. (2017). Pengaruh Penyajian Laporan Keuangan, Aksesibilitas Dan Sistem Akuntansi Keuangan Daerah Terhadap Akuntabilitas Pengelolaan Keuangan Daerah (Studi Empiris Pada SKPD Kabupaten Siunjung). JOM Fekon, 4(1).

Tampubolon, F. M., \& Hasibuan, A. B. (2019). Pengaruh Komitmen Organisasi, Kompetensi Sumber Daya Manusia dan Pemanfaatan Teknologi Informasi Terhadap Kualitas Laporan Keuangan Pemerintah. OIKOS: Jurnal Kajian Pendidikan Ekonomi dan Ilmu Ekonomi, 3(1).

Wulandari, M. (2018). Pengaruh Penerapan Standar Akuntansi Pemerintah dan Kompetensi Sumber Daya Manusia Terhadap Kualitas Laporan Keuangan Pemerintah Daerah Dengan Komitmen Organisasi Sebagai Variabel Moderasi. Jurnal Akuntansi, 6(3).

Yaqin, A., \& Jatmiko, B. (2018). Kontribusi Kompetensi Sumbser Daya Manusia, Standar Akuntansi Pemerintah dan Sistem Pengendalian Internal Pemerintah Terhadap Kualitas Laporan Keuangan Pemerintah : Studi Kasus Pada Satuan Kerja Perangkat Daerah Kabupaten Biak Numfor. Reviu Akuntansi dan Bisnis Indonesia, 2(1). 